\title{
set in the 21 st century
}

The first edition of set: Research Information for Teachers for the new century marks a fresh beginning for NZCER's long-established journal for teachers working in New Zealand schools. This is the first edition which concentrates almost solely on New Zealand issues for New Zealand teachers, and while future editions may involve an Australasian and wider focus, the major purpose will be to inform teaching and learning practices in New Zealand.

set has always been highly regarded by educationalists and educators, mainly for its focus on those issues which attend teaching, learning and assessment in school classrooms. It is very much this practical and applied approach which makes set different from other journals.

set for 2000 and beyond has gained the added impetus of an editorial board which comprises some of New Zealand's leading educators. NZCER is delighted to have this group providing advice and information about future editions.

set has also gained an additional perspective in that educational issues for children with special needs will feature more significantly than before, due in part to a very constructive relationship between NZCER and Specialist Education Services. There is little doubt that with growing awareness about special education in its broadest sense, and the increasing inclusion of children with special needs in mainstream schools, topical articles will be warmly welcomed by teachers and others alike.

As always, set has tried to address issues which are directly relevant to teachers working in New Zealand schools. This edition, for example, has three main areas of commentary, with a major focus on assessment which continues to attract considerable attention from professional and lay commentators:

professional development, with important contributions from Russell Bishop and Ted Glynn from the University of Waikato and Maureen Rutledge;

special education, with interesting observations on transition from Sue Wartmann, and the needs of Maori by Jill Bevan-Brown;

assessment, where there are five articles addressing contemporary issues in various aspects of assessment, monitoring and reporting.

Teachers and others with an interest in education will find great value in set, and will be pleased that this publication's established traditions and approaches will continue to be reflected in ways which are stimulating, informative and accessible.
Richard Watkins
Peter Cowley
Chief Executive
Chief Executive
NZCER
Specialist Education Services 